\title{
Migration governance in South America: The bottom-up diffusion of the Residence Agreement of Mercosur
}

\author{
Adriana Montenegro Braz \\ Facultad Latinoamericana de Ciencias Sociales (Flacso-Ecuador) / Departamento de Estudios Internacionales y Comunicación \\ Quito / Ecuador
}

\begin{abstract}
This article offers a complementary explanation to the diffusion theory that focuses on the process of governance emergence from a top-down perspective. This complementary explanation analyzes the bottom-up processes of diffusion and tested them by studying the policy formulation process in the Mercosur Residence Agreement (RA) signed in 2002. Based on interviews with key actors, documents, and academic literature, this article concludes that the RA was mainly the result of Brazilian and Argentinian negotiations. Brazil needed to boost regional cooperation after the Mercosur crisis, and considered that a joint migration amnesty could have a positive impact on the trading bloc's image. However, the Argentinian experience in migration issues allowed for a more coherent policy on the matter. Therefore, I maintain that the mode of interaction in the Residence Agreement negotiations was a bottom up diffusion process that allowed the regionalization of domestic policies.
\end{abstract}

Keywords: Mercosur; bottom-up diffusion process; regionalism; governance; migration.

\section{A governança migratória na América do Sul: a difusão de baixo para cima (bottom-up) do Acordo de Residência do Mercosul}

Este artigo oferece uma explicação complementar à teoria da difusão que explica o processo de surgimento da governança regional a partir de uma perspectiva de cima para baixo (top-down). Essa explicação complementar analisa os processos de difusão de baixo para cima (bottom-up), e os testa por meio do estudo da formulação de políticas no Acordo de Residência do Mercosul, assinado em 2002. Tomando em consideração entrevistas com atores destacados, documentos e literatura acadêmica, este artigo conclui que o Acordo foi principalmente o resultado das negociações brasileiras e argentinas. O Brasil em um primeiro momento considerou uma anistia migratória regional para melhorar a imagem do Mercosul. No entanto, a experiência argentina em questões de migração permitiu uma política mais coerente na matéria. Portanto, este trabalho conclui que o modo de interação na negociação do Acordo foi um processo de difusão de baixo para cima (bottom-up) que produziu a regionalização de políticas domésticas.

Palavras-chave: Mercosul; difusão de ideias de baixo para cima (bottom-up); regionalismo; governança; migrações.

\section{La gobernabilidad migratoria en Sudamérica: la difusión de abajo hacia arriba (ascendente) del Acuerdo de Residencia del Mercosur}

Este artículo ofrece una explicación complementaria a la teoría de la difusión que se centra en el proceso de emergencia de la gobernanza desde una perspectiva de arriba hacia abajo (top-down). Esta explicación complementaria analiza los procesos de abajo hacia arriba (bottom-up) de difusión y los prueba mediante el estudio de la formulación de políticas en el Acuerdo de Residencia del Mercosur, firmado en el 2002. En base a entrevistas con actores clave, documentos y literatura académica, este artículo concluye que el Acuerdo fue principalmente el resultado de las negociaciones brasileñas y argentinas. Brasil necesitaba impulsar la cooperación regional después de la crisis del Mercosur y consideró que una amnistía migratoria conjunta podría tener un impacto positivo en la imagen del bloque. Sin embargo, la experiencia argentina en temas de migración permitió una política más coherente en la materia. Por lo tanto, se sostiene que el modo de interacción en las negociaciones del Acuerdo fue un proceso de difusión de abajo hacia arriba (bottom-up) que posibilitó la regionalización de las políticas domésticas. Palabras clave: Mercosur; difusión de "abajo hacia arriba"; regionalismo; gobernanza; migración.

DOI: http://dx.doi.org/10.1590/0034-761220170069

Article received on March 31, 2017 and accepted on March 15, 2018.

[Original version]

A first version of this article was presented at ISA's 58th Annual Convention: Understanding Change in World Politics. February 22nd -25th, 2017, Baltimore, Maryland. FC23: Regionalism and Mercosur. In addition, a draft of this article was presented at Lasa's International Congress: Diálogos de Saberes. May 29th - April 1st, 2017, Lima, Peru. A203: Políticas migratorias regionales y subregionales en Latinoamérica frente a la reorientación política de gobiernos.

I would like to thank Cintia Quiliconi, Daniela Perrotta, the anonymous readers and the convention colleagues for their comments and suggestions to the manuscript of this article. 


\section{INTRODUCTION}

Unlike other cross-border issues such as the environment, international trade, organized crime, etc., there is no formal global governance structure to manage migration. The migration issues are dispersed and have been divided up among several international instruments dealing with various aspects of the topic (asylum, irregular migration, labor migration, etc.). In addition, there is no formal institutional migration framework that covers it comprehensively: the United Nations High Commissioner for Refugees (UNHCR) and the International Organization for Migration only address certain types of migration issues (Lavenex et al., 2016; Betts, 2010:8-13).

However, there is a global migratory governance and it takes different forms depending on the type of migration issue being addressed, and the levels of coordination established in each case. Regarding irregular migration and the free movement of people, there has been an enormous reluctance to adopt a comprehensive multilateral framework. Most of the cooperative efforts in this area have been addressed at the regional level, specifically within regional integration frameworks such as the Southern Common Market (Mercosur) and the European Union (EU). These frameworks have addressed the liberalization of internal mobility flows and irregular migration (Lavenex et al., 2016:457).

Literature on the subject has pointed out that the drivers of regional migration governance schemes follow either a top-down diffusion process of global scripts, which are adopted by some regional trading blocs, or an independent decision-making process that takes into consideration particular regional concerns or domestic interests. The first explanation concentrates on "common values" such as human rights - or supposedly successful regional models of migration management that are adopted by other regions because of a preference for readily available information to shape their decisions (Geiger and Pécoud, 2010; Lavenex et al., 2016). The independent decision making process explanation, on the other hand, points to particular regional or domestic interests, such as the spillover effect of the economic integration projects, or the domestic interests of the states (Awumbila et al., 2014; Lavenex et al., 2016).

This article offers a complementary explanation that takes into consideration not only regional or state interests, but also the ways in which their previous experiences influence other agents' preferences. This third approach focuses on the diffusion process and emergence of migration governance, but from a bottom-up point of view. It states that migration policy templates are not necessarily global, but in some cases, respond to a bottom-up process of regionalization of domestic policies. In this sense, this article considers that the negotiation of the Agreement on Residence for Citizens of the States Parties of Mercosur and Associated States - the Residence Agreement (RA) - signed in 2002, presents an excellent illustrative case for this complementary approach. It is necessary to point out that the RA constitutes a cornerstone in the advances of migration policy worldwide, because regional migrants only have to prove to be a national of one of the signatory states to access temporary or permanent residence in another signatory state. This was a stark difference from the traditional criteria of migratory legislation worldwide, where generally a residence permit has to be linked to labor, family reunification, studies, etc. (Nicolao, 2015:8-9; Ramírez Gallegos, Ceja and Coloma, 2017:66).

Consequently, this article examines how the model of migration governance in the RA was formed, and how this policy was diffused. This study also raises two supplementary analyses. The first one evaluates the modes of interaction that prevailed among the actors. In other words, was the RA a process of independent decision-making, or policy diffusion, and if so, which process or mechanism 
can explain its negotiation? The second one analyzes the kind of actors that were involved, their main interests, and the institutional conditions in the negotiation process of the RA.

In this article, I argue that the RA was mainly the result of the Brazilian and Argentinian negotiations. Brazil needed to boost regional cooperation after the Mercosur crisis, and considered that migration policies could have a positive impact in the regional trading bloc's image. However, the Argentinian experience with migration issues was one that allowed for a more coherent policy on the matter. In the end, the Argentinian experience was accepted by all members as the best policy option for the region.

The focus on Argentina and Brazil is not to suggest that the presence of the other state parties and signatory countries (Uruguay, Paraguay, Bolivia and Chile) was irrelevant during the negotiation. Clearly, an erosion of their support would have blocked the RA. However, the two larger countries played a fundamental role in the negotiation process, since they were the ones who came up with different policies containing different proposals, from which the other states could choose.

\section{WHY MIGRATION GOVERNANCE?}

The Agreement on Residence for Citizens of the States Parties of Mercosur and Associated States Residence Agreement (RA) is analyzed in this article as a construction of a regional migration governance. The analytical perspective of governance is understood as a set of rules, roles and social practices constructed above and beyond the nation state (Hall and Bevir, 2011:353), that can help to appreciate the different levels, institutional arrangements and types of coordination involved in the negotiation and adoption of this regional migration policy. Furthermore, the governance approach can better explain the multidimensional nature of the migration regime (Hall and Bevir, 2011:352) that deals with at least three different subfields: (i) an economic focus on facilitating mobility as a factor of production; (ii) a rights-based emphasis on the civil and social rights of migrants; and (iii) a security focus that stresses migration control and the fight against irregular migration (Betts, 2010:7; Lavenex et al., 2016). Finally, this analytical perspective can help to go beyond the state as a unified entity and understand the role of other public and private actors in the construction of this migration policy at different levels of analysis.

The concept of governance, can be associated with a wide variety of phenomena that can be classified according to whether they emphasize the policy, polity or political dimensions. The policy and polity dimensions emphasize the modes of political steering and the institutional system that forms the framework for political action. Governance in its political dimension is defined as the decisionmaking process in which agent's interests are developed to reach a concrete political goal, therefore it can be matched to the process of policymaking (Treib, Bähr and Falkner, 2005:4-6). Since the aim of this article is to discuss how the model of migration governance was formed, it will concentrate on the concept of governance in the political dimension.

\section{THE EMERGENCE OF REGIONAL MIGRATION GOVERNANCE}

Some authors (Lavenex et al., 2016) have argued that the emergence of the Mercosur Residence Agreement (RA) could be explained from an intergovernmental perspective, in which states and their agents cooperate in order to protect their geopolitical and economic interests, and the interests of their constituencies (Börzel, 2016:2-3; Oyarzún Serrano, 2008:100-104; Söderbaum, 2005:5-8, 
2009:480, 2011:10). In other words, cooperation results from independent decision making of one region faced with problems generated within the region (endogenous) or outside it (exogenous), such as the challenges created by the international economic interchange or the general process of globalization (Börzel and Risse, 2016).

Indeed, the RA responded to the Argentinian need to overcome the internal problem of irregular migration from neighboring states (Lavenex et al., 2016), and the Brazilian interest in addressing migration issues in order to strengthen the social agenda of Mercosur (Alfonso, 2012:47-52; OIM, 2014). However, the intergovernmental perspective cannot explain why the RA did not obey the legislation or the prior responses that the states parties had in relation to migration, and why it was so innovative for its time, not only in the region but also worldwide. In addition, this perspective cannot grasp how the previous Argentinian experiences with migration issues influenced the agents' choices.

The studies on diffusion, on the other hand, are concerned with the ways in which state cooperation, such as regionalism or regional governance, are shaped by interdependence (Risse, 2016:87-88). Diffusion can be understood as the "process by which an innovation is communicated through certain channels over time among the members of a social system" (Rogers, 1983:5). The rationale for the diffusion of the innovation is that actors, during a process of policy formation, prefer readily available information about which policies are the most effective or the most appropriate in a given situation (Risse, 2016:87-88). It has also been stated that geographic proximity, historical background, and political, institutional or ideological similarities play an important role in the policy adoption by a cluster of countries (Porto de Oliveira and Faria, 2017:19).

However, it is necessary to point out that one of the gaps in the literature on diffusion in international relations (IR) is that it only considers the top-down or horizontal dissemination of policies, leaving aside bottom-up processes. The vast majority of the literature on diffusion in IR has focused on the ways countries or regions have adopted Western approaches. In this sense, the formal institutionalization of the European Union (EU) (Breslin, Higgott and Rosamond, 2002:17; Söderbaum, 2013) or the governance schemes of international organizations (Finnemore, 1996) have been the templates to compare other forms of regional integration and regional governance around the world (Börzel, Lohaus and van Hüllen, 2013).

This led some authors to criticize the Western or Eurocentric approach, rejecting the tendency to see the Western models as paradigmatic cases to follow (Acharya, 2016:108-109; Constantine and Shankland, 2017:99; Porto de Oliveira e Faria, 2017:30). The scholarship on diffusion of ideas beyond Europe and the western countries is not new but has grown in recent years. In South America some scholars like Porto de Oliveira (2017) analyze how Brazil became an exporter of ideas and social policies and not only an importer, as local Brazilian authorities used their knowledge to promote the policy of participatory budgeting. Concerning policy diffusion in regional integration processes in South America, Perrotta (2016) analyzes the direct and indirect mechanisms of diffusion operated between Mercosur and the member states, regarding the regional policy for accreditation and quality assurances in higher education. In this sense, the author states that the regional accreditation of Mercosur is a case of diffusion of the Argentinian policies at the regional level.

In relation to migration, the article by Geddes and Arcarazo (2014) analyzes whether the EU and Mercosur present an example of convergence or divergence in relation to the diffusion of regional migration governance models. They conclude that the EU did not provide a model for the migratory 
policies in the region. Margheritis (2012:20)"abstract":"The negotiation of migration issues within the Latin American Southern Cone Market (Mercosur, on the other hand states that Argentina expanded the initiatives and encouraged the discussion of the migration norms within Mercosur. Finally, Brumat (2016:12-16, 467) through the analysis of Mercosur's migration policies between the 1991 and 2012, affirms that they are the result of complex interaction between the international, regional and national levels, although she states that it was the Argentinian policies that served as a model for the policies in the regional trading bloc.

However, these studies in regional migration issues do not concentrate on the process of diffusion and the mechanism at play within this process. Therefore, this article offers a complementary explanation for the emergence of regional governance that takes into account the regionalization of the domestic policies through the diffusion of ideas (Figure 1), and also explains the actors, levels and mechanisms at play in this process.

\section{FIGURE 1 BOTTOM-UP APPROACH TO THE DIFFUSION OF REGIONAL GOVERNANCE}

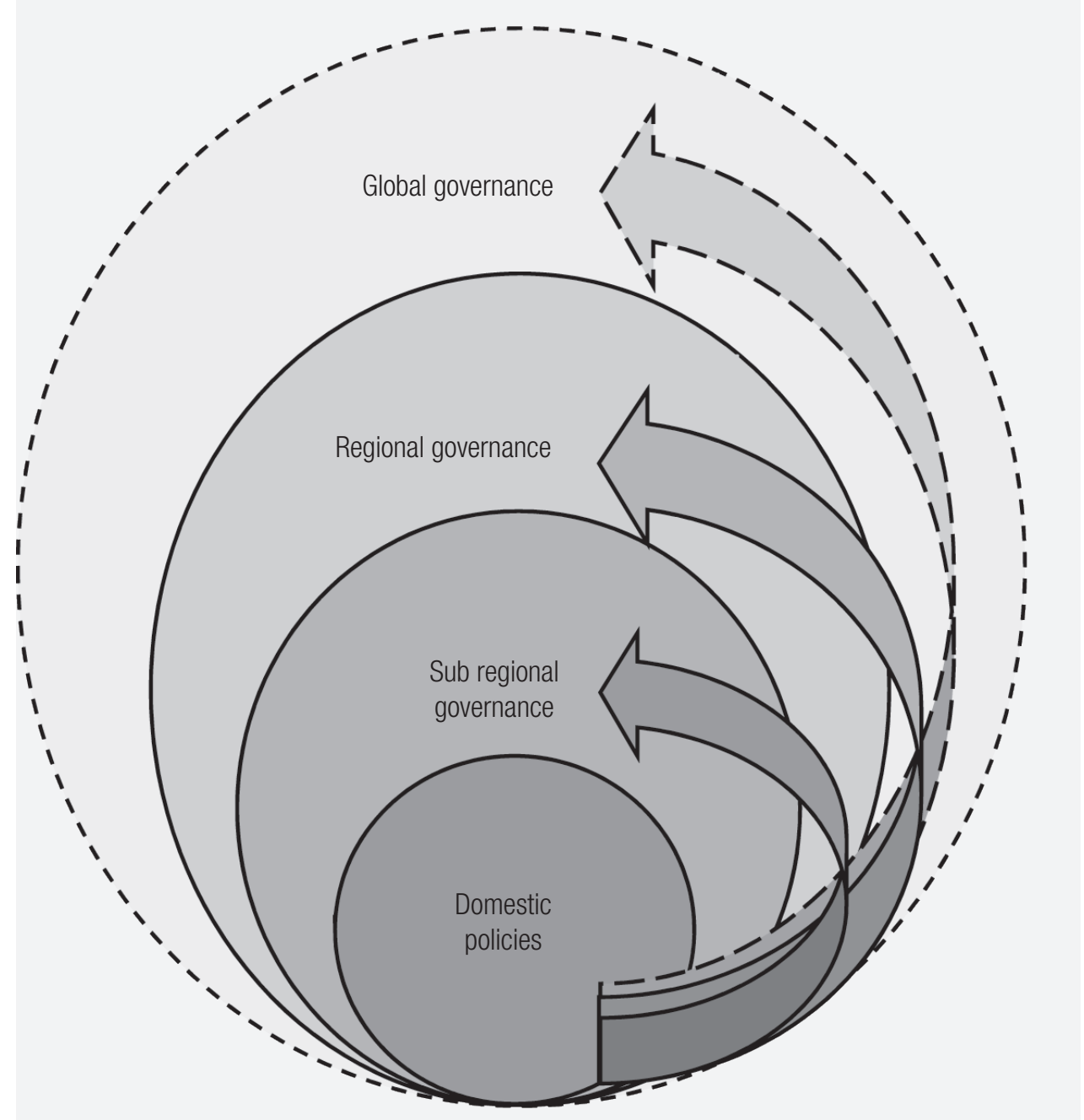

Sources: Porto de Oliveira (2017); Geddes and Arcarazo (2014); Margheritis (2012); Brumat (2016); Perrotta (2016). 


\section{DIFFERENT DIFFUSION MECHANISMS AND APPROACHES}

The literature on diffusion explains not only the existence of the phenomenon as such, but also the patterns and processes of diffusion. Generally, it recognizes four types of theories or mechanisms that explain the diffusion process: coercion, competition, learning and constructivism (Dobbin, Simmons and Garrett, 2007:449-450).

Coercion mechanisms operate when certain states, international organizations or private actors impose the adoption of a norm through the "manipulation of economic cost and benefits, and even the monopolization of information or expertise" (Dobbin, Simmons and Garrett, 2007:449-450). In migration matters the EU and the International Organization for Migration has supported migratory policies in Africa through funded projects, capacity building and transferring the monopolized expertise to the Economic Community of West African States (Ecowas) (Lavenex et al., 2016:468-469).

The competition mechanism also refers to changes in incentives, but it sees the incentives from the norm-takers perspective. In this sense, new policies do not come from powerful actors but from direct competitors. Although power plays a role in this mechanism, it is the market power or decentralized economic forces (rather than a powerful public or private actor) which leads to the adoption of a certain policy (Dobbin, Simmons and Garrett, 2007:457-459; Gilardi, 2011:15).

The learning mechanism involves a shift in individuals' beliefs or ideas. Learning occurs when new evidence discovered by norm-takers change their views. A new policy spreads when policy makers or political elites update their beliefs about what could work in their country, based on the experiments and experiences of other countries. Therefore, research on learning has to prove that evidence of policy efficacy increases the probability of its adoption elsewhere (Dobbin, Simmons and Garrett, 2007:450, 460-462).

However, it is necessary to take into consideration two aspects of the learning mechanism. The first has to do with the fact that policy diffusion is not necessarily a coordinate process where states make rational decisions with complete information (Porto de Oliveira and Faria, 2017:20). Policy makers commonly rely on cognitive shortcuts that are necessary for processing abundant information, and therefore the decision making process in the real world diverges form, the ideal rational choice postulates (Weyland, 2005:278-281, 2006:30, 43-48). The second aspect has to do with the fact that policy choices not only relate to policy outcomes, but also to political outcomes. Policy makers tend to assess the political feasibility of the policies presented to them. They also contrast this information with their own preferences, ideologies and prior beliefs. In other words, policy makers will favor a policy whose outcomes could match their political preferences (Gilardi, 2010:652-653).

Finally, the constructivist approach considers that, in order to analyze why a policy diffuses, it is necessary to understand how it became socially accepted ( Dobbin, Simmons and Garrett, 2007). In other words, policy choices are based on shared understanding or legitimate ends and appropriate means, where the action of adopting a policy evokes an identity or a role in a specific situation rather than the rational analysis of domestic variables (Gilardi, 2011; Osorio and Vergara, 2016:239)

The following sections analyze the diffusion of the Mercosur RA as a bottom-up process. Based on interviews with key actors, documents and academic literature on the subject, I reconstruct how 
a migration policy that was being developed in one state party, and its experience on the subject, was diffused in the regional arena. I employ a process-tracing approach to illustrate how the policy contained in the RA was diffused from the bottom up, and which mechanisms were preferred in the negotiation process.

\section{THE BACKGROUND OF THE DIFFUSION PROCESS}

\subsection{THE ARGENTINIAN EXPERIENCE IN MIGRATION POLICIES}

Argentina has historically been a country that received immigrants from Europe, mainly until 1930, and from Latin America, in a steady stream since the end of the 19th century (Novick, 2010:26; OIM, 2008). Therefore, international migration flows have deeply marked Argentinian society making it an important and debated issue in the history of the country (Modolo, 2016:202; Novick, 2012:8).

Between 1870-1930, there was a promotion of massive European immigration associated with the colonization process and the agro-exporting strategy of Argentina ${ }^{1}$. Hence, migration issues were regulated very early. The Avellaneda law of 1876, in force until 1981, formally stimulated European immigration and created the General Department of Immigrations within the Ministry of Interior that was in charge of formulating and controlling the policy in migration issues (Novick, 2010).

Between 1930 and 1976 the migration policies obeyed the economic and political strategies of the country. As a consequence, the migration policy was handled in a contradictory manner between openness and persecution of migrants, especially from the neighboring countries (Novick, 2000, 2010). However, by 1914 the migratory flow from Europe began to decrease, while the number of regional migrants began to increase steadily (Modolo, 2016:208; OIM, 2008:13).

When the coup d'état took place in 1976 and during the authoritarian government that lasted from 1976 to 1983, the national government established a new development strategy based on the deindustrialization and the liberalization of the economy. This was accompanied by migration policies that considered Latin American immigration as a "problem" that had to be resolved through police control and the express prohibition of labor for "illegal migrants". In 1981, the General Law on Migration and Promotion of Immigration was enacted (Ley Videla). This law, tied to the Doctrine of National Security, restricted regional migration and increased control of immigrants (Novick, 2010).

After the return to democracy (1984 onwards) the heavy external debt, industrial recession, and the fall of international prices of agricultural products, started a period of economic adjustment, in a clear trend towards neoliberalism that had an impact on migration policies. During this time, the norm sanctioned in 1981 was reinforced in its legitimacy through the adoption of two regulations that were aimed at implementing it: the first one developed by Alfonsín in 1987 and the second by Menem in 1994. Both regulations contained a restrictive immigration policy and a security approach to the migratory phenomenon (Novick, 2010).

\footnotetext{
${ }^{1}$ Demographically, the massive European immigration influenced the size of the population that went from 1.8 million habitants in 1870 , to nearly 12 million by the end of 1920 . Indec (2010).
} 
It is necessary to point out that since the 1950s, a large number of undocumented migrants have regularized their situation in Argentina thanks to amnesty decrees. Between 1949 and 1992 the country implemented six migratory amnesties ${ }^{2}$ (Pacecca and Courtis, 2008:43) These exceptional measures constituted key elements for open and non-selective population policies. While not all of these measures were aimed at regional aliens, they benefited most from it (Novick, 2010). Nonetheless, these amnesties were temporary measures that did not provide a definitive solution to the situation of irregular migrants. The continuous opening and then restriction of the migratory policy in Argentina increased the number of irregular migrants forcing the amnesties to be recurrent rather than exceptional measures. Moreover, these measures imposed a heavy administrative and economic burden on the Argentinian state, and especially for the Ministry of Interior (Alfonso, 2012:54-60).

Despite the problems generated by the short-term policies, by the turn of the century the law of 1981 was still in force. However, since 1996 there has been an active participation of non-governmental organizations (NGOs), international organizations, etc. along with the Congress and the executive institutions in charge of migration to modify this military law. Several projects were presented without success; however in 2001 it was possible to present a unified project to Congress that was later approved in 2003 (Novick, 2012). The project was ambitious, but its participatory nature laid out a general vision of migration that allowed for a long-term strategy that would facilitate mobility as well as a more open and tolerant stance towards migrants. As one of the experts in migration issues of Argentina said: "[...] the draft of the new immigration law was already under discussion [...], somehow this discussion transferred the concern that we had for Argentina itself to the Mercosur sphere".

Whilst the discussion of the future migratory law gradually modified the discourses of state bureaucrats, the migratory amnesties proved to be insufficient to cope with the problem of irregular migration. These two aspects, as we shall see in the following paragraphs, shaped the proposal in the last instance for a more coherent migration policy from Argentina to Mercosur.

\subsection{MERCOSUR AND ITS AGENDA ON MIGRATION}

In 1991 Argentina, Brazil, Paraguay and Uruguay signed the Asunción Treaty that gave birth to Mercosur, whose main objectives were to liberalize intraregional trade in goods and the formation of a common market by $1994^{4}$. However, the treaty's clear stress on having a commercial agenda, in tune with the model of new regionalism and a neo-liberal program, led some scholars to speak of the social deficit of Mercosur (Di Pietro Paolo, 2013; Perrotta and Vázquez, 2010:17). Therefore, this treaty conceptualized people's mobility in terms of market mechanisms, as part of the free circulation of the factors of production such as capital, goods, services and labor (Brumat, 2016:335; Cernadas, 2011:90; Pérez Vichich, 2007).

\footnotetext{
${ }^{2}$ Amnesty Decree No 15.972 of 08 July 1949. Amnesty Decree No 3.364 of 04 August 1858. Amnesty Decree No 49 of 03 January 1964. Amnesty Decree No 87 of 11 January 1974. Amnesty Decree No 780 of 12 January 1984. Amnesty Decree No 1.033 of 24 June 1992 (Sassone, 1997:4).

${ }^{3}$ Author's translation. NPV: Personal interview [October 2016]. Interviewer: Adriana Montenegro. Buenos Aires.

${ }^{4}$ The state parties of Mercosur committed to reach a common market in the European way, leaving the agenda open for the incorporation of new issues of different kinds (Botto, 2015:24; Peixoto, Batista and Perrotta, 2017:100).
} 
During the transition period towards the goal of creating a common market, no entity dealt directly with migration issues. Only two subgroups ${ }^{5}$ under the Common Market Group (the executive organ of the integration process), dealt indirectly with migration. The first was Subgroup 2 of customs matters, which dealt with some issues related to the movement of people. The other was Subgroup 11, which dealt with labor issues (Saracho, 2011). However, the latter subgroup began a series of actions envisioning a future that embraced the free circulation of people, hypotheses that were reinforced after the "Cronograma de las Leñas" which established a timetable for the common market (Mármora and Cassarino, 1997).

Nevertheless, by 1994 it was clear that the goal of forming a common market was ambitious, and it was necessary to redefine the goals and the schedule of the regional integration process. The Protocol of 'Ouro Preto', signed in December of 1994, inaugurated a second stage that gave priority to the formation of the customs union, thus focusing on the agenda of free movement of goods and capital (Botto, 2015:24; Peixoto, Batista and Perrotta, 2017:100). During this second stage, migration issues were less front-and-center than before. New Subgroup 10 on "Labor, Employment and Security," (heir to the late Subgroup 11), worked under the premise that the free circulation of labor was excluded (Brumat, 2016:347; Camargo, 2010:502; Mármora and Cassarino, 1997; Martínez Pizarro and Stang, 2006:96; Pérez Vichich, 2007:259); therefore, migration issues were treated as "labor movements in border zones and largely [placed] back at the national level of policy-making" (Margheritis, 2012:6).

Although the Protocol of Ouro Preto focused on trade and commerce, the second half of the decade saw a progressive deterioration in economic cooperation within the trade bloc. During this time member countries' compliance with the agreements and diplomatic and commercial tensions developed. By 1998, levels of intra-regional trade began to fall drastically (Gómez Mera, 2013:1416). Meanwhile, in the late 1990 's the discussion on common social and labor issues regained momentum. In 1996, an Economic Social and Consultation Forum, created by the Protocol of Ouro Preto, began its activities. This forum was a channel for participation and consultation with business associations, unions and NGOs, on social and labor matters, which included migration issues. Later, in 1997, a Multilateral Agreement on Social Security was signed for the establishment of common norms to guarantee the right to social security benefits for Mercosur nationals within the trade bloc (Margheritis, 2012:6).

However, the drastic fall of intra-regional trade vis-à-vis the diplomatic and commercial tensions reached their climax after the double economic crises in Brazil (1999) and Argentina (2001) (Caetano, 2011:20-41; Sanahuja, 2007:82-85). But, the states parties remained committed to the integration process within the trade bloc and therefore took several measures in response. First, following the Argentinian financial collapse, Brazil made some temporary trade concessions to its weakened partner (Gómez Mera, 2013:15-20). In addition, members proposed an institutional reengineering of Mercosur with a less intergovernmental view. In this regard, the Administrative Secretariat was transformed into a Technical Secretariat, and the Permanent Review Tribunal of Mercosur was created, the aim of which was to function as a dispute settlement system. Both of these innovations occurred in 2002 (Caetano, 2011:42-43).

\footnotetext{
${ }^{5}$ The aim of the subgroups was to call for special meetings to deal with issues of interest.
} 
It is necessary to point out that in July of 2002 Brazil initiated its Pro Tempore Presidency (PTP), headed by President Fernando Henrique Cardoso. Mercosur was always thought of as an alternative hub from which Brazil could reinforce its position in the South American region (Quiliconi, 2014:245-246). However, taking into consideration the need to reinforce the regional trading bloc, Cardoso initiated a series of activities to further promote the integration process during his last Pro Tempore Presidency, in particular considering the salience of Mercosur during the Brazilian election campaign that was held in 2002. Luis Inácio Lula da Silva, leader of the Workers' Party in Brazil and the candidate who would later win the presidential election, consistently promoted the trading bloc and its social aspects during his campaign (Caetano, 2011:44). In this regard, the Head of the Department of Foreigners of the Ministry of Justice in Brazil, who participated in the negotiation of the Agreement stated:

We wanted (the states parties) at that moment to work hard as countries, in the Ministries of Justice, to transform Mercosur in a more consistent Mercosur. It was pretty much attached to a trade agreement. We wanted to transform Mercosur in a more consistent common bloc. How could we do that? We could do it by focusing on granting rights and with visible things that would transform Mercosur in a reality for its citizens. ${ }^{6}$

Therefore, in addition to the reengineering of Mercosur, the financial crises allowed for the deepening of the political and social dimension of the trading bloc (Briceño Ruiz, 2013). The end of neoliberal convergence and the economic and political problems that the countries of the Southern Cone experienced in the late 1990's had an impact on the trading bloc's agenda. Mercosur went from being centered on commercial issues, to include political, social and productive ones, which encompassed a more open stance and discourse towards migration issues (Arcarazo and Freier, 2015:176).

\section{THE NEGOTIATION OF THE MERCOSUR RESIDENCE AGREEMENT}

On 6 December 2002 the presidents of the Mercosur countries, plus those of Bolivia and Chile, signed the Residence Agreement (RA) after a series of negotiations that took place during the Pro Tempore Presidency of Brazil. In order to understand the negotiation process of the RA it is necessary to note that its first discussions took place in the Specialized Migration Working Group (MWG) that was part of the Meeting of Ministries of Interior. This Meeting was established in 1996 within the Common Market Council with a strong vision on security matters. The first meetings of the MWG focused on migration border control in the territory of the party members. However, by the beginning of the $21^{\text {st }}$ century the MWG began to make a series of decisions in migration issues with an agenda less centered on security matters (Alfonso, 2012:37-41; Mercosur, 2015:4-20).

As mentioned, in 2002, Brazil assumed the Pro Tempore Presidency of Mercosur. Cardoso wanted to leave a mark on the integration process, in particular considering the salience of

\footnotetext{
${ }^{6}$ Author's translation. LPTB: Skype interview [September 2017]. Interviewer: Adriana Montenegro.
} 
Mercosur during the Brazilian election. The end of the neoliberal convergence and the Mercosur crisis led the regional leaders to initiate activities to further promote the regional trading bloc that included its institutional reengineering and the promotion of its political and social dimensions (Caetano, 2011:44).

On 30 August 2002, during a meeting of the MWG that took place in Porto Alegre (Brazil), the Brazilian delegation presented a project for a migratory amnesty for Mercosur. The project proposed to start a joint legalization process in all the countries of the trading bloc. It was thought an exceptional measure that would favor Mercosur's nationals within a period of sixth months and could promote the social aspects of integration (Alfonso, 2012:48-49).

In October 2002, during the meeting that took place in Curitiba (Brazil), Argentina (through its Ministry of Interior) presented a draft of the RA, as a counter-proposal to the Brazilian suggestion to implement a regional amnesty. As mentioned before, Argentina had a long experience in migration issues, and according to the census of 2001, the migrants from bordering countries corresponded to $60 \%$ of the foreigners that the country had received. ${ }^{7}$ In particular, Argentina had witnessed how migratory amnesties processes implemented in its country (followed by periods of closing borders) only increased the number of people in an irregular situation (Alfonso, 2012:51; Modolo, 2017:48). Regarding this issue, the Legal Director of the National Direction of Migration of Argentina, who participated of the negotiation of the Agreement said:

The Argentinian delegation considered the Brazilian proposal interesting, but we also noticed, according to our own experience, that the amnesty was not a long-term solution. We already knew from our history that amnesties involve a short-term patch at any given time. ${ }^{8}$

Indeed, the employees of the Migration Department (DNM) of the Ministry of Interior of Argentina, who designed the RA draft, knew beforehand that it was impossible to stop migration movements in countries with large borders such as Argentina. Therefore, it was necessary to implement real alternatives as they catalogued their policy proposal for Mercosur. This view considered that a permanent immigration regularization policy would allow Mercosur member states to know who the people that entered their territory were. Secondly, they considered that irregular migrants easily end up as illegal migrants and become victims of smuggling, human trafficking and irregular jobs (Alfonso, 2012:50). Finally, there was a need to show a difference with the migration policies of the countries of the North. Mercosur member states were especially concerned with the violation of the fundamental rights of their citizens abroad after 9/11 (Nicolao, 2015:4).

As shown, the reasons stated by the DNM for the implementation of the RA have an administrative and security view of migration, in tune with the issues discussed at the Mercosur Meeting of the Ministries of Interior. Although the RA grants fundamental rights to migrants from signatory countries, from the interviews conducted with former DNM employees, their main concerns were about the identification of migrants within the territory of member states and the control of illegal

\footnotetext{
${ }^{7}$ Migration Statistics according to the origin country. INDEC (2001).

${ }^{8}$ Author's translation. AA: Personal interview [October 2016]. Interviewer: Adriana Montenegro. Buenos Aires.
} 
activities that can be related to migration. However, this was an advanced view when compared to the security's migration laws of Mercosur's member states, some of which were established during periods of dictatorship. Moreover, this was a reformist perspective by international standards, where most of the migration laws were based on the closure of borders.

This change of mind cannot be ascribed only to the DNM employees, but as stated before, from the accumulation of the Argentinian experience on the issue. It is therefore necessary to consider that Argentina was going through a process of discussion of its future migration law since the mid1990s. It was a process of intense negotiations between Congress, the executive institutions in charge of migration issues, and the civil society. These participatory discussions under a more human and social rights perspective, influenced the discourse on migratory issues in general, and shaped the future migration policy, not only in Argentina but in Mercosur as well.

After the Argentinian proposal, delegates went to an intermediate room to discuss the topic more profoundly. The main negotiators in this room were the Argentinian DNM, the Brazilian delegates, from the Department of Foreigners of the Ministry of Justice and from the Migration Division of Itamaraty. Finally, the members emerged and Brazil announced that it tabled its proposal of amnesty in favor of the Argentinian Delegation project ${ }^{9}$. Paraguay and Uruguay noted that they needed to make prior consultations before making a decision (Alfonso, 2012:51).

At the next meeting, which was held on 8 November 2002 in Salvador (Brazil), the different delegations brought their inquiries to the RA under analysis. Argentina was in charge of the consultations, but Brazil, through its Ministry of Justice, took the leadership in the negotiation process and got the different delegations to accept the proposal. After three days of hard discussions, the Ministries of Interior subscribed to the RA (Alfonso, 2012:51-52). In December 2002, the Presidents of Mercosur's member States, and of Bolivia and Chile, signed the RA, which was taken as an achievement of the last months of the Cardoso administration and deepening of the political and social dimension of the trading bloc.

\section{THE NEGOTIATION OF THE RESIDENCE AGREEMENT AS A DIFFUSION PROCESS}

Some authors considered that the RA reflected the domestic priorities in the participating countries (Lavenex et al., 2016). The intergovernmental perspective could offer a proper explanation for the timing and form that the regime was introduced. However, this explanation does not take into account how the previous Argentinian experiences with migration issues, influenced agents' preferences. Why, in the end, did they refuse the Brazilian offer for the migration amnesty, and preferred to take into consideration the information Argentina made readily available showing how things could have worked if Mercosur implemented the amnesty as a long term solution for migration problems?

This article argues that an explanation of a bottom-up diffusion process could better explain the negotiation process. As stated, the extensive experience of the DNM employees with migratory amnesties in the Argentinian territory allowed them to understand that these administrative

\footnotetext{
${ }_{9}^{9}$ AA: Personal interview [October 2016]. Buenos Aires. LPTB: Skype interview [September 2017]. Interviewer: Adriana Montenegro.
} 
procedures, followed by periods of closing borders, only increased the number of people in irregular situations. A more long-term migration policy was needed. Furthermore, the participatory discussions of the future migration law influenced the discourse on migratory issues in Argentina, which in the last instance had an impact on the DNM proposal and, consequently, influenced the migration policy in Mercosur.

However, if the RA is to be considered a process of policy diffusion it is necessary to sort out which type of mechanisms were in place. Taking into consideration the different mechanisms presented, this article proposes to analyze the process of negotiation of the RA from a rationalist perspective, an epistemological stance adopted bearing in mind the need to simplify reality and actors' preferences. Therefore, this study concentrated on the interests of Argentina and Brazil, since the two larger countries were the ones that came up with the different proposals of which the other member states could choose.

In addition, this analysis considers that the learning mechanism is the one that best explains the adoption of the RA from a rationalist perspective. If learning occurs when actors update their beliefs about what could work in their country, based on the experiments and experiences of other countries, then it could be said that the Argentinian experience of what went wrong with their migration amnesties drove away member states from Brazil's previous proposal. The policies of the RA had not been implemented in Argentina before, and therefore member states could not conduct a thorough cost-benefit analysis. However, as stated before, policy diffusion is not necessarily a coordinated process where states make rational decisions with complete information (Porto de Oliveira and Faria, 2017:20). In the case analyzed, member states used cognitive shortcuts that drove attention to the policy failures of Argentina, giving a chance to the yet unknown policy.

Finally, it is necessary to emphasize that the RA fulfilled a political objective: promote the social dimensions of Mercosur after a time of commercial and political turbulence in the regional trading bloc. Therefore, the RA matched the preferences and prior beliefs, not only of the bureaucrats but also of the political elites of the time.

\section{CONCLUSION}

This article offered a complementary explanation for the diffusion theory that focuses on the diffusion process of governance emergence from a top-down perspective. This complementary explanation was tested by studying how the model of migration governance in the Mercosur Residence Agreement was formed. To that end, I evaluated the actors that were involved in the RA, their main interests, the institutional conditions underlying negotiation, and the modes of interaction that prevailed among these actors. Based on interviews with key actors, documents and academic literature on the subject, I conclude that the RA was mainly the result of Brazilian and Argentinian negotiations. Brazil needed to boost regional cooperation after the Mercosur crisis, and considered that a joint migration amnesty could have a positive impact on the regional trading bloc's image. However, the Argentinian experience in migration issues was the one that allowed for a more coherent policy in the matter, which in the end was accepted by member states as the best policy option, not only in its technical but also in its political aspects. 
RAP | Migration governance in South America: The bottom-up diffusion of the Residence Agreement of Mercosur

Therefore, I argue that the mode of interaction between the actors was a bottom-up learning process of the Argentinian policy. As mentioned, the extensive experience of the DNM employees with migratory amnesties in Argentina allowed them to realize that these administrative procedures only increased the number of immigrants in irregular situations. A more long-term migration policy was needed not only for Argentina but also for the region as a whole. Furthermore, the participatory discussions of the future migration law influenced the discourse on migratory issues in Argentina, which in the last instance had an impact on the DNM proposal, and later in the region. 


\section{REFERENCES}

ACHARYA, Amitav. Regionalism beyond EUcentrism. In: BÖRZEL, Tanja A.; RISSE, Thomas (Org.). The Oxford handbook of comparative regionalism. Oxford: Oxford University Press, 2016. p. 109-130.

ALFONSO, Adriana. Integración y migraciones. El tratamiento de la variable migratoria en el Mercosur y su incidencia en la política argentina. Buenos Aires: OIM, 2012. (Cuadernos Migratorios, 3).

ARCARAZO, Diego A.; FREIER, Luisa Feline. Discursos y políticas de inmigración en Sudamérica: ¿hacía un nuevo paradigma o la confirmación de una retórica sin contenido? REHMU. Revista Interdisciplinar de Mobilidade Humana, v. 23, n. 44, June 2015. Available at: <http://research-information. bristol.ac.uk/en/publications/discursos-y-politicasde-inmigracion-en-sudamerica-hacia-un-nuevoparadigma-o-la-confirmacion-de-una-retoricasin-contenido(0eee $96 \mathrm{fd}-4 \mathrm{db} 7-431 \mathrm{~b}-\mathrm{a} 913$ 7189189391b9).html>. Accessed on: 25 Apr. 2016.

AWUMBILA, Mariama et al. Across artificial borders: an assesment of labour migration in Ecowas region. Ghana: IOM.ACP, 2014. (Research report, n. ACPOBS/2014/PUB05).

BETTS, Alexander. Migration governance: alternative futures. Le Grand-Saconnex: OIM, 2010. (Background Papers WMR 2010). Available at: <http://publications.iom.int/system/files/pdf/ wmr2010_migration_governance_alternative _ futures.pdf>. Acceso em: 25 de Apr. 2017.

BÖRZEL, Tanja A. Theorizing regionalism: cooperation, integration and governance. In: BORZEL, Tanja A.; RISSE, Thomas (Org.). The Oxford Handbook of comparative regionalism. Oxford: Oxford University Press, 2016. p. 41-63.

BÖRZEL, Tanja A.; LOHAUS, Mathis; VAN HÜLLEN, Vera. Governance transfer by regional organizations: following a global script? Berlim: Collaborative Research Center, 2013. (SFBGovernance Working Paper Series, n. 42).

BÖRZEL, Tanja A.; RISSE, Thomas. Introduction: framework of the handbook and conceptual clarifications. In: BÖRZEL, Tanja A.; RISSE, Thomas (Org.). The Oxford handbook of comparative regionalism. Oxford: Oxford University Press, 2016. p. 3-15.
BOTTO, Mercedes. América del Sur y la integración regional: ¿Quo vadis? Los alcances de la cooperación regional en el Mercosur. Revista Confines, v. 11, n. 21, p. 9-38, 2015.

BRESLIN, Shaun;HIGGOTT, Richard; ROSAMOND, Ben. Regions in comparative perspective. Coventry: University of Warwick, 2002. (CSGR Working Paper, n. 107/02). Available at: <https://warwick.ac.uk/ fac/soc/pais/research/researchcentres/csgr/papers/ workingpapers/2002/wp10702.pdf $>$. Accessed on: 25 Mar. 2017.

BRICEÑO RUIZ, José. Ejes y modelos en la etapa actual de la integración económica regional en América Latina. Estudios Internacionales, v. 45, n. 175, 2013. Available at: <www.revistaei.uchile.cl/ index.php/REI/article/view/27352>. Accessed on: 21 Nov. 2015.

BRUMAT, Leiza Maricel. Políticas migratorias y libertad de circulación en el Mercosur (1991-2012). 2016. Thesis (Doctor Degree in Political Science) - Programa de Doctorado en Ciencias Sociales, Facultad Latinoamericana de Ciencias Sociales, Sede Académica Argentina, Buenos Aires, 2016. Available at: $<$ http://repositorio.flacsoandes.edu.ec/ handle/10469/10634\#.Wob953xumM8>. Accesed on: 15 Aug. 2017.

CAETANO, Gerardo. Breve historia del Mercosur en sus 20 años. Coyunturas e instituciones (19912001). In: CAETANO, Gerardo (Org.). Mercosur 20 años. Montevideo: Cefir, 2011. p. 21-74. Available at: <www10.iadb.org/intal/intalcdi/PE/2011/08347. pdf $>$. Accessed on: 23 Feb. 2016.

CAMARGO, Sonia. O processo de integração regional: fronteiras abertas para os trabalhadores do Mercosul. Contexto Internacional, v. 32, n. 2, p. 489-517, Dec. 2010.

CERNADAS, Pablo C. Luces y sombras en la legislación migratoria latinoamericana. Nueva Sociedad, n. 233, p. 68-86, 2011.

CONSTANTINE, Jennifer; SHANKLAND, Alex. From policy transfer to mutual learning? Political recognition, power and process in the emerging landscape of international development cooperation. Novos Estudos Cebrap, v. 36, n. 1, p. 9-122, 2017.

DI PIETRO PAOLO, Luis José. La dimensión social del Mercosur: recorrido institucional y perspectivas. 
Revista del Observatorio Social, n. 12, nov. 2013. Available at: <www.sciencespo.fr/opalc/sites/ sciencespo.fr.opalc/files/mercosur\%20social.pdf $>$. Accessed on: 3 Mar. 2017.

DOBBIN, Frank; SIMMONS, Beth; GARRETT, Geoffrey. The global diffusion of public policies: social construction, coercion, competition, or learning? Annual Review of Sociology, v. 33, 2007. Available at: <http://scholar.harvard.edu/dobbin/ publications/global-diffusion-public-policiessocial-construction-coercion-competition-or-lea>. Accessed on: 5 Feb. 2016.

FINNEMORE, Martha. National interests in international society. Ithaca: Cornell University Press, 1996. (Cornell Studies in Political Economy).

GEDDES, Andrew; ARCARAZO, Diego Acosta. Transnational diffusion or different models? Regional approaches to migration governance in the European Union and Mercosur. European Journal of Migration and Law, v. 16, n. 1, p. 19-44, 2014.

GEIGER, Martin; PÉCOUD, Antoine (Org.). The politics of international migration management. London: Palgrave Macmillan, 2010. Available at: <http://link.springer. com/10.1057/9780230294882>. Accessed on: 1 June 2016.

GILARDI, Fabricio. Trasnational diffusion: norms, ideas and policies. In: CARLSNASES, Walter; RISSE, Thomas; SIMMONS, Beth (Ed.). Handbook of international relations. Thousand Oaks: Sage Publications, 2011. p. 453-477. Available at: <www. fabriziogilardi.org/resources/papers/gilardi_ handbook_IR_v2.pdf $>$. Accessed on: 27 Feb. 2016.

GILARDI, Fabricio. Who learns from what in policy diffusion processes? American Journal of Political Science, v. 54, n. 3, p. 650-666, July 2010.

GÓMEZ MERA, Laura. Power and regionalism in Latin America: the politics of Mercosur. Notre Dame: University of Notre Dame Press, 2013.

HALL, Ian; BEVIR, Mark. Global governance. In: BEVIR, Mark (Org.). The Sage handbook of governance. London: Sage Publications, 2011. Available at: $<$ http://sk.sagepub.com/reference/hdbk_ governance>. Accessed on: 10 May 2016. p. 352-366.

INDEC. Evolución de la población total según censos nacionales de población. Total del país. Censos 1869-
2010. 2010. Available at: <www.indec.gov.ar/ftp/ cuadros/poblacion/n020101.xls >. Accessed on: 15 Aug. 2017.

INDEC. Migraciones. Cuadros estadísticos. Censo 2001. Población extranjera empadronada en el país por lugar de nacimiento, según sexo y grupos de edad. 2001. Available at: <hwww. indec.gov.ar/nivel4_default.asp?id_tema_1=2\&id_ tema_2=188id_tema_3=78>. Accessed on: 15 Aug. 2017.

LAVENEX, Sandra et al. Regional migration governance. In: BÖRZEL, Tanja A.; RISSE, Thomas (Org.). The Oxford handbook of comparative regionalism. Oxford: Oxford University Press, 2016. p. $457-485$.

MARGHERITIS, Ana. Piecemeal regional integration in the post-neoliberal era: negotiating migration policies within Mercosur. Review of International Political Economy, v. 20, n. 3, p. 541575, 2012. p. 541-575.

MÁRMORA, Lelio; CASSARINO, María. Las migraciones y su tratamiento institucional en el MERCOSUR. Relaciones Internacionales, n. 12, 1997. Available at: <http://hdl.handle.net/10915/10089>. Accessed on: 23 Feb. 2016.

MARTÍNEZ PIZARRO, Jorge; STANG, María Fernanda. El tratamiento migratorio en los espacios de integración subregional sudamericana. Papeles de Población, v. 12, n. 48, p. 77-106, June 2006.

MERCOSUR. Foro Especializado Migratorio del Mercosur y Estados Asociados: reunión de ministros del interior. Memoria institucional. Montevidéu: Mercosur, [20??]. Available at: <www. migraciones.gov.ar/foro_migratorio/pdf/memoria_ institucional_n.pdf>. Accessed on: 6 Mar. 2015.

MODOLO, Vanina. Análisis histórico-demográfico de la inmigración en la Argentina del Centenario al Bicentenario. Papeles de Población, v. 22, n. 89, p. 201-222, Sept. 2016.

MODOLO, Vanina. Política migratoria regional. El caso de la residencia del Mercosur (2002-2011). Revista Aportes para la Integración Latinoamericana, n. 26, p. 40-58, June 2017.

NICOLAO, Julieta. Las migraciones en la agenda del Mercosur. El rol de Argentina en el Foro Especializado Migratorio. Revista Electrónica 
de Estudios Internacionales, n. 29, 2015. p. 1-32. Available at: <www.reei.org/index.php/revista/ num29/notas/migraciones-agenda-mercosur-rolargentina-foro-especializado-migratorio $>$. Accessed on: 2 Mar. 2016.

NOVICK, Susana. La política migratoria argentina, a contrapelo de la tendencia mundial. Voces en el Fenix, Buenos Aires, n. 21, p. 7-11, Dec. 2012.

NOVICK, Susana. Políticas migratorias en Argentina: experiencias del pasado, reformas actuales y expectativas futuras. In: ZURBRIGGEN, Cristina; MONDOL, Lenin (Org.). Estado actual $y$ perspectivas de las políticas migratorias en el Mercosur. Montevideo: Flacso-Uruguay, 2010. p. 25-53.

NOVICK, Susana. Políticas migratorias en la Argentina. In: OTEIZA, Enrique; NOVICK, Susana; ARUJ, Roberto (Org.). Inmigración y discriminación: políticas y discursos. Buenos Aires: Prometeo, 2000. Available at: <http://webiigg.sociales.uba. ar/pobmigra/archivos/migrar.pdf $>$. Accessed on: 2 Mar. 2016.

OIM. Estudio sobre experiencias en la implementación del Acuerdo de Residencia del Mercosur y Asociados. In: CONFERENCIA SURAMERICANA SOBRE MIGRACIONES, 14., 2014, Lima. Anais... Lima: OIM, 2014.

OIM. Perfil migratorio de Argentina 2008. Perfiles migratorios América Latina. Buenos Aires: OIM, 2008. Available at: <http://publications.iom.int/ system/files/pdf/argentina_profile.pdf $>$. Accessed on: 15 Mar. 2016.

OSORIO, Cecilia; VERGARA, José Miguel. La difusión de políticas públicas. Estado del arte y contribuciones para la disciplina en América Latina. Política. Revista de Ciencia Política, v. 54, n. 2, p. 235-254, 2016.

OYARZÚN SERRANO, Lorena. Sobre la naturaleza de la integración regional: teoría y debates. Revista de Ciencia Política, v. 28, n. 3, p. 95-113, 2008.

PACECCA, María Inés; COURTIS, Corina. Inmigración contemporánea en Argentina: dinámicas y políticas. Santiago de Chile: Naciones Unidas, 2008. (Población y Desarrollo, 84).

PEIXOTO BATISTA, Juliana; PERROTTA, Daniela. El Mercosur en el nuevo escenario político regional: más allá de la coyuntura. Desafíos, v. 1, n. 30, p. 91134, 2017.

PÉREZ VICHICH, Nora. Fundamentos teóricos del tratamiento de la movilidad de personas en Mercosur. Entelequia: Revista Interdisciplinar, n. 4, p. 255-270, 2007.

PERROTTA, Daniela. Mercosur, regulatory regionalism and contesting projects of higher education governance. In: ROBERTSON, Susan et al. (Org.). Global regionalisms and higher education projects, processes, politics. London: Edward Elgar Publishing, 2016. p. 228-252. Available at: <hwww. elgaronline.com/view/9781784712341.00020.xml>. Accessed on: 6 Jan. 2018.

PERROTTA, Daniela; VÁZQUEZ, Mariana. El Mercosur de las políticas públicas regionales. Las agendas en desarrollo social y educación. Montevideo: Cefir, 2010. (Documento de trabajo 010).

PORTO DE OLIVEIRA, Osmany. International policy diffusion and participatory budgeting: ambassadors of participation, international institutions and transnational networks. Switzerland: Springer, 2017.

PORTO DE OLIVEIRA, Osmany; FARIA, Carlos Aurelio Pimenta de. Policy transfer, diffusion, and circulation: research traditions and the state of the discipline in Brazil. Novos Estudos Cebrap, v. 36, n. 1, p. 13-32, 2017.

QUILICONI, Cintia. Competitive diffusion of trade agreements in Latin America. International Studies Review, v. 16, n. 2, p. 240-251, June 2014.

QUILICONI, Cintia. Modelos competitivos de integración en el hemisferio occidental: ¿liderazgo competitivo o negación mutua? Revista Cidob d'Afers Internacionals, n. 102-103, p. 147-168, Sept. 2013.

RAMÍREZ GALLEGOS, Jacques; CEJA, Ireri; COLOMA, Soledad. Ah, usted viene por la visa Mercosur: integración, migración y refugio. Quito: Celag, 2017.

RISSE, Thomas. The diffusion of regionalism. In: BÖRZEL, Tanja A.; RISSE, Thomas (Org.). The Oxford handbook of comparative regionalism. Oxford: Oxford University Press, 2016. p. 87-108.

ROGERS, Everett M. Diffusion of innovations. 3. ed. New York: Free Press, 1983. 
SANAHUJA, José Antonio. Regionalismo e integración en América Latina: balance y perspectivas. Pensamiento Iberoamericano, n. 0, p. 75-106, 2007.

SARACHO CORNET, Teresita Nelly. El Mercosur social: génesis y evolución. In: MOLINA DEL POZO, Carlos (Org.). Evolución histórica y jurídica de los procesos de integración. Buenos Aires: Eudeba, 2011. p. 363-381.

SASSONE, Susana María. Inmigració limítrofe ilegal en la Argentina: ¿exclusión o integración? In: ENCUENTRO DE GEÓGRAFOS LATINOAMERICANOS, 6., 1997, Buenos Aires. Anais... Buenos Aires: Comisión Organizadora Nacional de geógrafos, 1997. Available at: $<$ http://observatoriogeograficoamericalatina. org.mx/egal6/Geografiasocioeconomica/ Geografiadelapoblacion/106.pdf $>$. Accessed on: 1 Feb. 2017.

SÖDERBAUM, Fredrik. Comparative regional integration and regionalism. In: LANDMAN, Todd; ROBINSON, Neil (Org.). The Sage handbook of comparative politics. London: Sage Publications, 2009. p. 477-496. Available at: <http://sk.sagepub. com/reference/hdbk_compolitics/n27.xml $>$. Accessed on: 9 Mar. 2016.

SÖDERBAUM, Fredrik. The international political economy of regionalism. In: PHILLIPS, Nicola
(Org.). Globalizing international political economy. Basingstoke: Palgrave Macmillan, 2005. Available at: $<$ https://he.palgrave.com/page/detail/globalizinginternational-political-economy-nicola-phillips/? sf $1=$ barcode\&st $1=9780333965047>$. Accessed on: 25 May 2016.

SÖDERBAUM, Fredrik. Theories of regionalism. In: BEESON, Mark; STUBBS, Richard (Org.). Routledge handbook of Asian regionalism. New York: Routledge, 2011. p. 11-21.

SÖDERBAUM, Fredrik. What's wrong with regional integration? The problem of Eurocentrism. Robert Schuman Centre for Advance Studies, n. 64, 2013. Available at: <www.ssrn.com/abstract $=2399858>$. Accessed on: 10 Jan. 2017.

TREIB, Oliver; BÄHR, Holguer; FALKNER, Gerda. Modes of governance: a note towards conceptual clarification. Viena: Eurogov, 2005. (European Governance Papers, n. 05-02).

WEYLAND, Kurt. Bounded rationality and policy diffusion: social sector reform in Latin America. Oxford: Princeton University Press, 2006. Available at: <www.jstor.org/stable/j.ctt7rsvd $>$. Accessed on: 2 Feb. 2016.

WEYLAND, Kurt. Theories of policy diffusionm Latin American Pension Reform. World Politics, v. 57, n. 2, p. 262-295, 2005.

\section{Adriana Montenegro Braz}

Doctoral Candidate at Facultad Latinoamericana de Ciencias Sociales (Flacso-Ecuador), Departamento de Estudios Internacionales y Comunicación. E-mails: admontenegrofl@flacso.edu.ec; montenegroadriana@ hotmail.com. 